\title{
Very old patelliform gastropods from the Early Cambrian of China: Reconsideration of the systematic position of Archaeotremaria
}

\author{
Yu Wen \\ Nanjing Institute of Geology \& Palaeontology, Chinese Academy of Sciences, \\ Nanjing, 210008, People's Republic of China \\ Present address: Department of Earth \& Planetary Sciences, Western Australian Museum, \\ Francis Street, Perth, Western Australia, 6000, Australia. Email: wenyu@hotmail.com
}

\begin{abstract}
Archaeotremaria polytremata $\mathrm{Yu}$ from the Lower Cambrian Maidiping Member of the Hongchunping Formation of Sichuan, China, was originally described as a primitive monoplacophoran. A restudy of the holotype and paratype has led to a reconsideration of its systematic position. A. polytremata has a patelliform shell with a series of median-dorsal tremata extending from the apex to the anterior margin and periodic rugae. The species is now reassigned to the Gastropoda, rather than Monoplacophora.
\end{abstract}

\section{INTRODUCTION}

The fossils redescribed and refigured in the present paper were collected by the writer and his colleagues in 1977 from the upper part of the Lower Cambrian Maidiping Member of the Hongchunping Formation. The section is situated at the west side of Gaoqiao village, about $14 \mathrm{~km}$ south of the city of Emei, Sichuan, China. The Maidiping Member is about $32 \mathrm{~m}$ in thickness; it is composed mainly of light to dark inequigranular arenaceous dolomites with collophane. The member conformably overlies the Precambrian Maoergang Member of the Hongchunping Formation and is overlain conformably by the Lower Cambrian Jiulaodong Formation (Yin et al. 1980) (Figure 1). The Maidiping Member is one of several units in the Yangtze region of China which are rich in micromolluscan fossils. Specimens of Archaeotremaria polytremata, often occur together with interesting and characteristic forms of the Meishucun Stage, such as Watsonella yunnanensis (He and Yang), Circotheca subcurvata $\mathrm{Yu}$, Merismoconcha multisegmentata $\mathrm{Yu}$, Maidipingoconus maidipingensis (Yu) and Yangtzeconus priscus Yu. These fossils are widely distributed in eastern Yunnan, western Hubei and southwestern Shaanxi.

The patelliform fossil Archaeotremaria polytremata $\mathrm{Yu}$, was described by the writer in 1979 as a member of the Class Monoplacophora. A restudy of the holotype and paratype has concentrated on some characters which previously were uncertain, such as the concentric periodic rugae, and a development of tremata throughout ontogeny. These observations provide the basis for reconsidering the systematic position of the genus.

Illustrated specimens are housed in the Nanjing Institute of Geology and Palaeontology, Chinese
Academy of Sciences, Nanjing, People's Republic of China.

\section{SYSTEMATIC PALAEONTOLOGY}

Class Gastropoda Cuvier, 1797

Subclass Prosobranchia Milne-Edwards, 1848

Order Archaeogastropoda Thiele, 1925

Suborder Bellerophontida Ulrich and Scofield, 1897

\section{Superfamily Archaeotremarioidea Yu, 1979}

Family Archaeotremariidae $Y u, 1979$

(= Granoconidae $Y u, 1979)$

\section{Diagnosis}

Shell minute to small, univalve, bilaterally symmetrical, patelliform, cyrtoconic; with a series of tremata on the median dorsal side.

\section{Remarks}

The family Granoconidae Yu was established by the writer in 1979 p. 265, based on the genus Granoconus $\mathrm{Yu}, 1979$. Subsequent detailed comparison demonstrated that Granoconus is quite similar to Archaeotremaria Yu, 1979: 249, especially in the dorsal tremata on tubular projections. For this reason, the genus Granoconus was relocated in the family Archaeotremariidae $\mathrm{Yu}, 1979$ by the writer in 1987. It follows therefore that the family Granoconidae should be considered a junior synonym of the family Archaeotremariidae (Yu, 1987b: 170). 


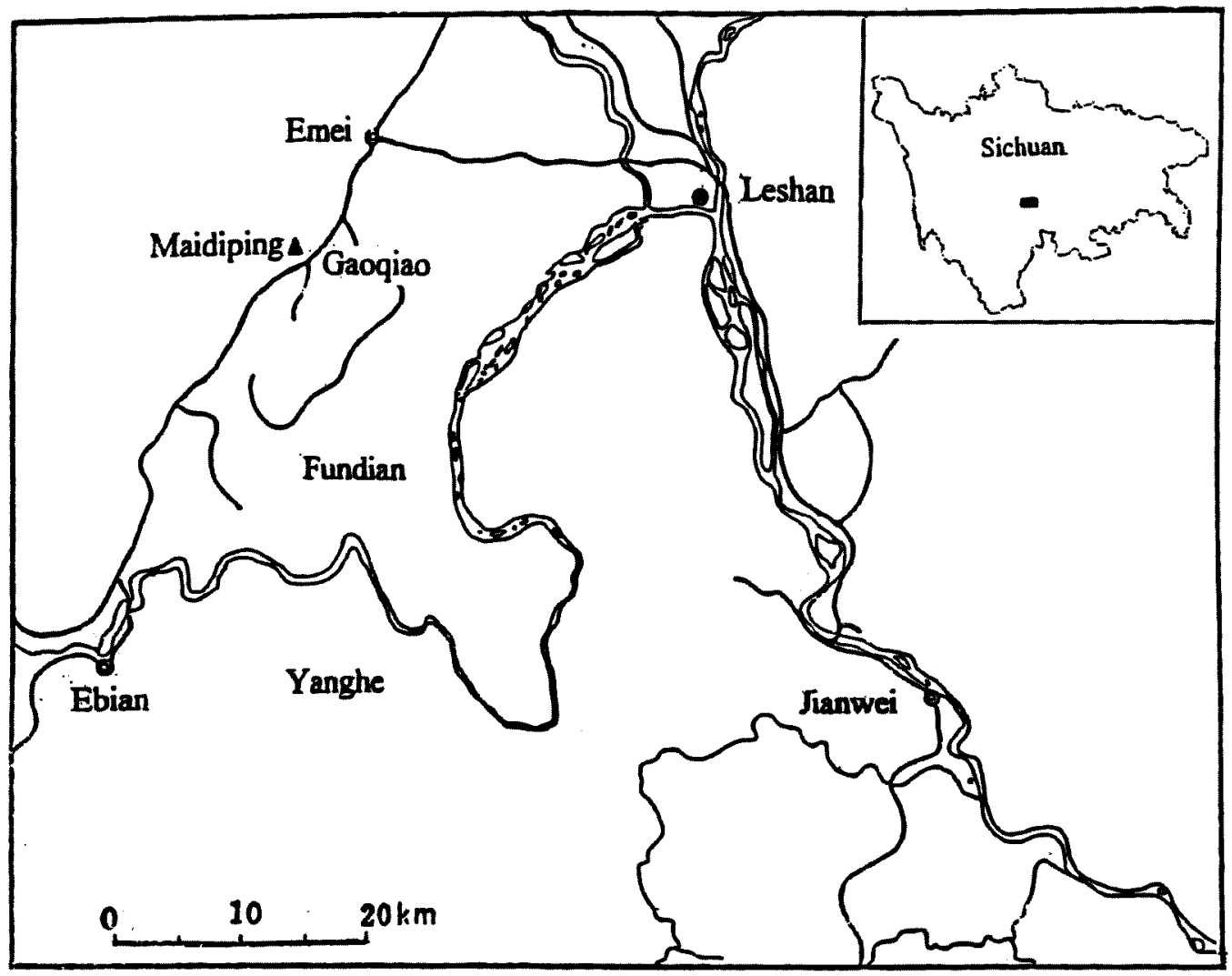

Figure 1 Sketch map showing the fossil locality.

This family was erected to include three genera: Archaeotremaria Yu, 1979 from the Lower Cambrian Maidiping Member of Hongchunping Formation in western Sichuan, Granoconus Yu, 1979 from the Lower Cambrian Huangshandong Member of Tongying Formation in western Hubei, China and Rozanoviella Missarzhevsky, 1981 from the Lower Cambrian Tommotian to Atdabanian Stages of western Mongolia.

\section{Genus Archaeotremaria Yu, 1979 emend.}

Archaeotremaria Yu, 1979: 249, 264; Dzik, 1981: 119; Yu, 1983: 1572; 1987a: 55; 1987b: 170; 1990: 144; 1996: 211.

\section{Type species}

Archaeotremaria polytremata Yu, 1979: 249, 264, by original designation, from Lower Cambrian Maidiping Member of Hongchunping Formation, at Maidiping of Emei, Sichuan, China.

\section{Diagnosis}

Minute, patelliform, bilaterally symmetrical. Protoconch unknown. Apex obtusely rounded. Dorsum broadly rounded with an obtuse dorsal ridge in the central part, a series of tremata on the tubular projections on the median dorsal ridge, the tremata divided into two small pores, which were gradually filled with shell secretion during growth, the last one remaining open and serving as an exhalant function. Aperture large, expanded, subelliptical in form. Surface ornamented with concentric, periodic rugae, growth lines and pustules. Muscle scars unknown.

\section{Remarks}

In the presence of the tremata on the tubular projections on the median dorsal ridge and ornamentation of numerous small pustules, this genus resembles Granoconus Yu, 1979 from the Lower Cambrian Huangshandong Member of Tongying Formation of the Hujintan section of Yichang, Hubei (Yu, 1979: 250, 265; 1987b: 173; 1990: 145). However, Granoconus has a cyrtoconic shell, a comparatively narrow dorsal ridge and the trema is a single pore.

The general form of the shell and the presence of a series of tremata in the central part of the dorsum, suggests comparison with Rozanoviella Missarzhevsky, 1981 from the Lower Cambrian Tommotian to Atdabanian Stages of western Mongolia (Missarzhevsky, 1981: 27; Zhegallo, in Voronin et al. 1982: 46; Zhegallo in Esakova and Zhegallo, 1996: 164), but in Archaeotremaria the shell has larger and fewer tremata on the tubular projections, of which the last remains open. In Rozanoviella, the numerous small tremata on the median dorsal ridge are chain-like in appearance; 
in Archaeotremaria, the tremata are divided into two small pores, whereas in Rozanoviella the trema is a single pore.

In Archaeotremaria, the presence of a series of median dorsal tremata is similar to the condition in the bellerophontoidean gastropods Tremanotus Hall, 1865, both sharing such common features as: 1) bilaterally symmetrical shell, 2) the possession of a series of median dorsal tremata on the tubular projections, 3) the periodic rugae, and 4) an expanded aperture. However, there are still great differences between them, particularly in the shell being patelliform in Archaeotremaria, while the isostrophic form characterises Tremanotus. In Archaeotremaria, the tremata are divided into two small pores, whereas in Tremanotus, the tremata are a single pore. In the former, the apex is situated at the posterior part of the shell, but in the latter, the earliest whorl is succeeded by the later closely coiled ones.

In the general aspect of the tremata on tubular projections, Archaeotremaria somewhat resembles Knightites Moore, 1941 from Upper Pennsylvanian of Kansas. However, Knightites has an isotrophic shell, spiral ornament and projecting tubes on either side of the selenizone.

\section{Archaeotremaria polytremata $\mathrm{Yu}$} Figures $2 \mathrm{~A}-\mathrm{I} ; 3 \mathrm{~A}-\mathrm{D}$

Archaeotremaria polytremata Yu, 1979: 249, plate 4, figures 6-11, text-figure 6; 1987a: 55 , plate 3 figures 3, 4; 1987b: 171, plate 33, figures 1-5; plate 34 , figures $1-5$, text-figures 21,$52 ; 1990$ : 162 , plate 7 , figures $1-3 ; 1993 ; 241$, text-figure 23.

\section{Material Examined}

\section{Holotype}

NIGP 54460, in the collections of the Nanjing Institute of Geology and Palaeontology, Chinese Academy of Sciences. Collected by the writer in 1977 from the Lower Cambrian Maidiping Member of Hongchunping Formation at Maidiping of Emei, Sichuan, China.

\section{Paratype}

NIGP 54461 from same locality and horizon as the holotype.

\section{Description}

Minute, patelliform, bilaterally symmetrical. Protoconch unknown. Apex bluntly rounded, slightly in posterior part of centre. Subapical area scarcely rounded and inclined to the posterior margin. Lateral slopes broadly rounded. Dorsal side broadly rounded, moderately convex, gradually sloping to the anterior margin, with an obtuse dorsal ridge in the central part of the dorsum, and a series of tremata on the median dorsal ridge. The earliest tremata unclear, about seven tremata can be observed on the mould, usually on the tubular projections. First trema very small and moderately protruding, closed by shell secretion, situated about one-third of the posterior margin from the shell. Second and third tremata small, subcircular, a little protruding and closed by shell secretion. The fourth trema strongly protruding, inclined forward, broadly rounded in the basal part, gradually tapering toward the top, situated at about one-third of the anterior margin from the shell, just on the periodic ruga and also closed. The fifth trema slightly protruding, poral margin slightly broken, but the general form and periodic ruga can be seen. The poral wall of the sixth trema broken, remaining a subcircular pore. Pore small, situated between the middle part of the two periodic rugae. The last one is the highest and biggest one in the series of tremata, subelliptical in plan view. Poral wall thickened, upper part of poral wall a little convexly arched first, then gradually, concavely inclined and extending downward, forming a V-shaped septum, dividing the trema into two small pores; pore subreniform in outline and equal in size, located near the anterior margin, and serving as an exhalant function.

Surface ornamentation of the shell is not preserved, although some regularly distributed periodic rugae are still visible on the apical area, and sub-apical area, especially the latter, where at least five periodic growth rugae can be seen on the anterior part of the dorsum (Fig. 3A). The inner periodic growth ruga is complete, forming a ring on the dorsum, situated behind the second trema. The second and third periodic growth rugae are similar morphologically to the inner one, located behind the third and fourth tremata. The fourth and fifth periodic growth rugae are not well preserved due to the periphery of the shell being slightly broken. Aperture large, occupying most of the ventral side, subelliptical in shape, posterior margin narrowly rounded, lateral sides broadly arcuated, anterior margin not known in detail.

The paratype, shown in Figures 2E-I, 3C-D, is a well preserved internal mould. It is very small, possibly a juvenile. In plan view, the shell is elliptical in shape. Dorsal side strongly arched, broadly rounded, gradually sloping to anterior margin. Posterior margin narrowly rounded, lateral slopes gently arcuated. The centre of the shell has an obtuse dorsal ridge, with four tremata on tubular projections. First two tremata very small, scarcely projecting, located near the apical area. Third trema distinctly protruding and inclined forward, broadly rounded in the basal part, slowly constricted to the top; poral wall thin and subelliptical in shape, narrowly rounded posteriorly, broadly curved laterally, narrow anteriorly, divided into two small 


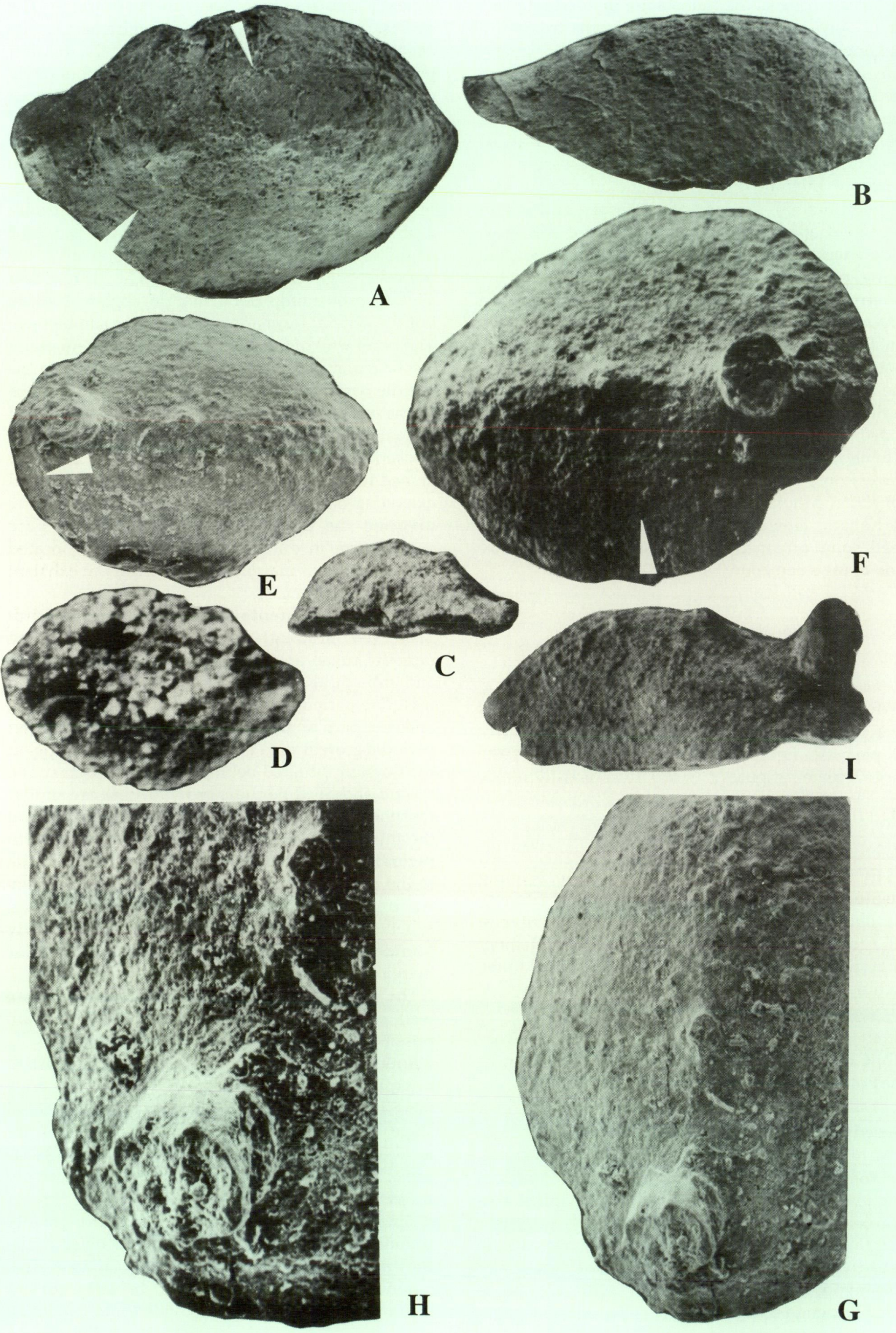


pores by a thin septum and closed by shell secretion. The last tremata is the largest and highest, strongly protruding and slightly inclined forward; poral opening circular in plane view, slightly flared and reflected, the anterior part seems to extend a little forward (Figure 2F); nearly heart-shaped in anterior view (Figures $2 \mathrm{~F}-\mathrm{H}, 3 \mathrm{D}$ ). Posterior surface of poral wall is thickened, and a little swollen. Lateral parts slightly convex initially, middle part flatly concave, gradually sloping and extending downward, forming a " $\mathrm{V}$ " shaped septum dividing the opening trema into two small pores, which are equal in size and reinform in outline.

Surface ornamented with numerous small pustules, among which can be observed several rows of pustules that seem to correspond to periodic growth rugae. Muscle scars unknown.

\section{Dimensions (mm)}

$\begin{array}{llll} & \text { Length } & \text { Height } & \text { Width } \\ \text { NIGP 54460 } & 1.500 & 0.546 & 1.000 \\ \text { NIGP 54461 } & 0.588 & 0.210 & 0.448\end{array}$

\section{Horizon and locality}

Maidiping Member of Hongchunping Formation at Maidiping of Gaoqiao, Emei.

\section{Discussion}

In 1979, the writer established the family Archaeotremariidae $\mathrm{Yu}, 1979$ within the Class Monoplacophora based on the genus Archaeotremaria Yu, 1979. In addition to the type genus, Yu (1987b) assigned Granoconus Yu, 1979 from the Lower Cambrian Huangshandong Member of the Tongying Formation of Yichang, Hubei, China and Rozanoviella Missarzhevsky, 1981 from the Lower Cambrian Tommotian to Atdabanian Stages of western Mongolia to this family. Nevertheless, he pointed out that Archaeotremaria possessed a row of tremata on the tubular projections on the dorsal ridge that differed from the all known genera in the Monoplacophora (Yu, 1979: 249). The term Class Monoplacophora was abandoned by Peel (1991), who proposed using the Class Tergomya, Horny 1965, for forms possessing a bilaterally symmetrical exogastric shell with bilaterally symmetrical muscle scars (Peel, 1991a; BergMadsen and Peel, 1994; Yochelson, 1994; Horny' and Peel, 1996; Webers and Yochelson, 1999; Yu and Yochelson, 1999).

The species Archaeotremaria polytremata is very small. The very small size (about 1-2 mm) of the Early Cambrian molluscs has been discussed in detail by many scholars (Runnegar and Jell, 1976, Runnegar and Pojeta, 1985; Chaffee and Lindberg 1986; Salvini-Plawen, 1990; Dzik, 1991; Peel, 1991; Haszprunar, 1992). The holotype of $A$. polytremata is $1.500 \mathrm{~mm}$ in length, with seven tremata on the dorsal ridge. The paratype is a juvenile $0.588 \mathrm{~mm}$ long, with four tremata.

The molluscan character of this species taxon is shown the following combination of characters: bilaterally symmetrical, patelliform shape, with apex located slighty posterior of centre; aperture ventral; dorsal side broadly rounded, the tremata series marked by tubular projections along the median dorsal ridge, which were infilled sequentially with shell growth. The last of these remained open. serving the exhalant function. At least five periodic growth-rugae can be seen on the dorsal side of the internal mould.

Among the Early Paleozoic molluscan fauna, there are a few genera of bellerophontoidean gastropods which have one or more tremata on the median dorsal side, such as the Lower Cambrian Granoconus trematus Yu, 1979 (Yu, 1979, plate III, figures 33-35, text-figure $7 ; 1987 \mathrm{~b}$, plate 33 , figures $6-9$, text-figure 53; Figure 3E-3F), Rozanoviella atypica Missarzhevsky, 1981 (Missarzhevsky 1981, plate III, figure 9, textfigure 2; Zhegallo in Voronin et al., 1982, plate I, figures 10-11; Zhegallo in Esakova and Zhegallo 1996, plate XX, figures 4-5; Figure 3G-3I); the Middle Ordovician-Silurian Tremanotus Hall, 1865, (Lindström, 1884; Knight, 1941; Knight et al., 1960; Horny', 1963; Yochelson, 1967; Peel, 1972, 1991b) and Salpingostoma Roemer, 1876 (Lindström, 1884; Knight, 1941, 1952; Knight et al., 1960; Peel, 1991b). Nevertheless, so far as I am aware, no monoplacophoran or tergomyan has dorsal tremata.

It is worth noting that $A$. polytremata, not only has a series of tremata on tubular projections from the apex to the anterior margin on the median dorsal side, but there also seems to be a periodicity in its formation. With the growth of the shell, the previously formed trema is gradually filled with shelly substance and then subsequently a new trema develops, remaining open and serving as an exhalant outlet. It can be demonstrated that the tremata develop throughout

Figure 2 A-I, Archaeotremaria polytremata Yu. A-D. holotype NIGP 54460. A, dorsal view, showing seven tremata on the median dorsal ridge from the apex to anterior margin and some concentric, periodic growth rugae (arrow), x 55. B, left lateral view, x 50. C, right lateral view, $\times 36 . \mathrm{D}$, apertural view, $x 40$. E-I, paratype NiGP 54461 . E, oblique dorsal view, showing four tremata on tubular projections on the median dorsal ridge and some traces of concentric, periodic growth rugae (arrow), $\times 120$. F, dorsal view, showing the tremata and sculpture, $x$ 180. $G-H$, enlargement of the last two tremata and sculpture, showing the tremata are divided into two small pores by a V-shaped septum, $\times 200$ and $\times 300$. I, right lateral view, showing four narrow bands, $\times 120$. 

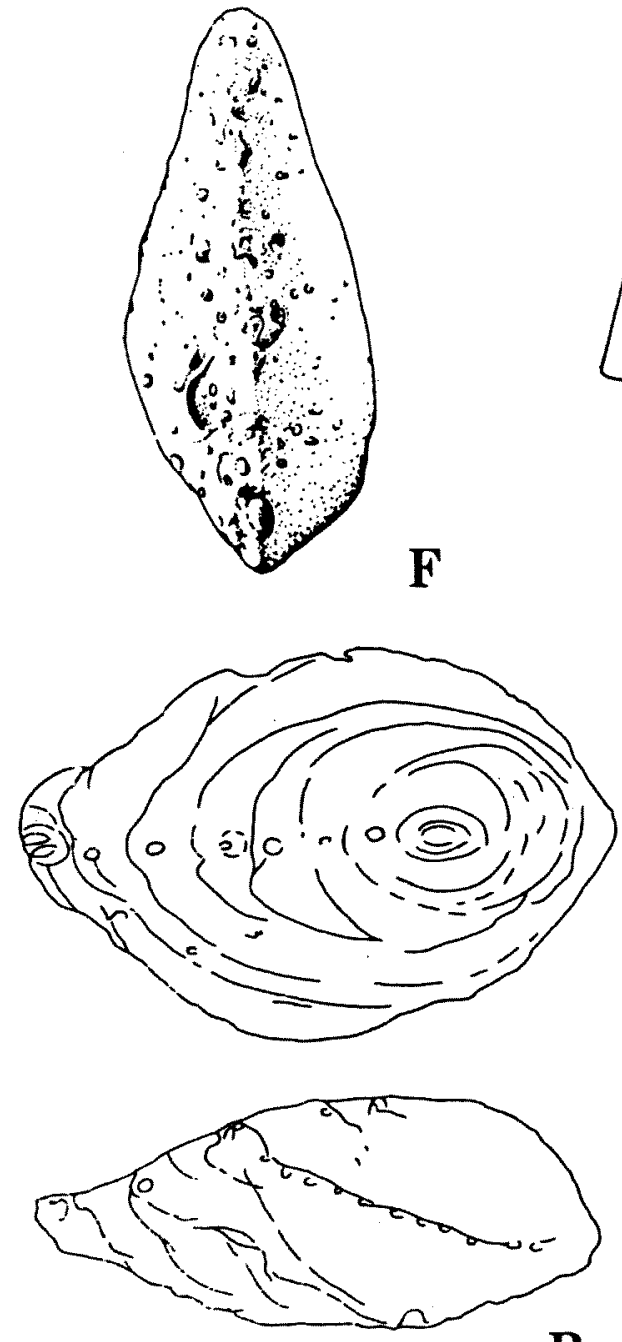

B

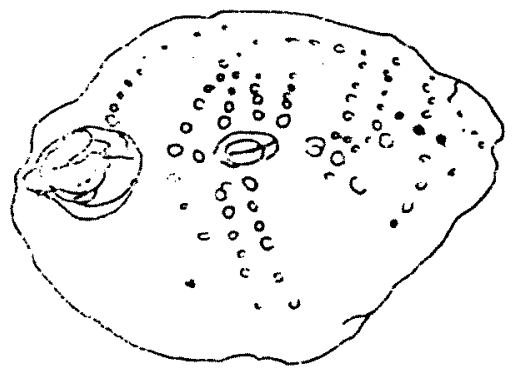

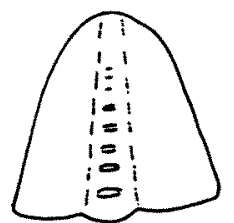

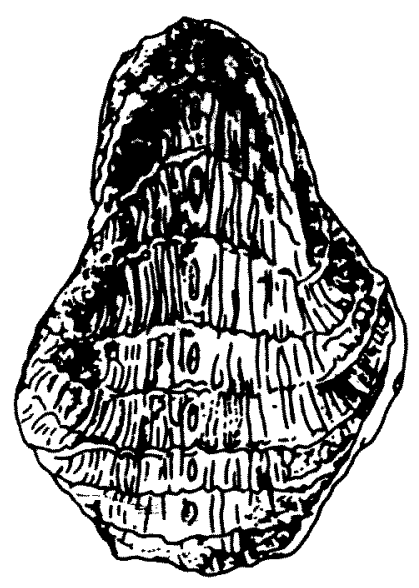

$\mathbf{J}$
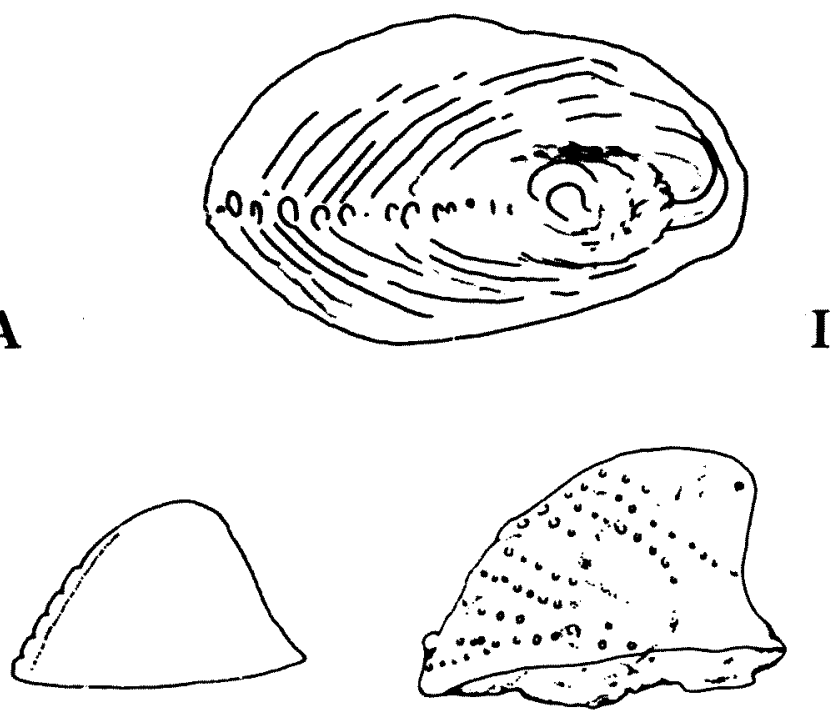

G

$\mathbf{E}$

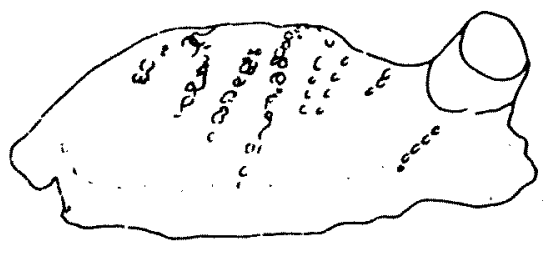

C

D

Figure 3 A-D, Archaeotremaria polytremata Yu. A-B, holotype NIGP 54460. A, dorsal view, showing tremata and concentric, periodic growth rugae, $x 38.5$. B, left lateral view, showing tremata on the tubular projections, $x$ 35. C-D, paratype NIGP 54461. C, dorsal view, showing the tremata and some pustules, $x$ 85. D, right lateral view, showing four narrow bands, $x$ 85. E-F, Granoconus trematus $Y u$, holotype NIGP 54455. E, left lateral view, showing tremata on the tubular projections $\times 32$. F, anterior view, $x 42$. Lower Cambrian of Hubei, China (after Yu Wen, 1979). G-I, Rozanoviella atypica Missarzhevsky, G. left lateral view, x 30. H, anterior view, x 30. Lower Cambrian of western Mongolia. (after Missarzhevsky, 1981). I, dorsal view, x 55. Lower Cambrian of western Mongolia (after Zhegallo in Voronin et al., 1982) J. Tremanotus longitudinalis Lindstrom. dorsal view, x 1. Middle Silurian of Gotland, Sweden, (after Lindström, 1884).

ontogeny in Archaeotremaria. The tremata of $A$. polytremata are divided into two small pores, indicating that Archaeotremaria may be a gastropod having paired ctendia. However, the living monoplacophoran Neopilina galatheae Lemche (1957, figures 1-4) and Vema ewingi Clarke and Menzies
(1959, figures 1-2) have five and six pairs of gills respectively. Pilina liaoningensis $\mathrm{Yu}$ and Yochelson (1999, figures 2a, 2b, 3f, 3g, 4a, 4b) from the Upper Cambrian Wanwankou Member of Fengshan Formation of Liaoning, China has five pairs of scars of the gill cavity. 
The form of the tremata and their presumed function in Archaeotremaria are very similar to those of the Middle Ordovician Tremanotus Hall, 1965. Though distant from each other in absolute geologic time, such gaps within plausible or speculative lineages are not unusual in view of our far from complete knowledge of Early Paleozoic molluscs. Ongoing new discoveries and research can be expected to close some of the gaps separating Early Cambrian and Middle Ordovician trematose molluscs. It has long been argued that bellerophontids are most similar to pleurotomarians (Meek, 1866; Lindström, 1884; Ulrich and Scofield, 1897). During the last fifty years, there have been many contributions concerning similarities between bellerophontoidean gastropods and pleurotomarians (Knight, 1947, 1952; Knight et al. 1960; Yochelson, 1967, 1984; Peel, 1972, 1991b; Batten, 1975; Golikov and Starobogatov, 1975; Linsley, 1978; McLean, 1984). The appearance of the primitive patelliform Archaeotremaria in the Early Cambrian, may provide some evidence for further discussion on the relationship between the bellerophontoidean gastropods and the pleurotomarians. Moreover, the presence of regularly distributed periodic rugae is another noteworthy feature in this genus; at least five concentric, periodic growth rugae can be seen on the internal mould, periodically spaced, usually between the tremata. This character is similar to that of Tremanotus portlocki Reed (1920-1921, plate XIII, figure 4) from the Ordovician of Tyrone, United Kingdom, Tremanotus longitudinalis Lindström (1884, plate III, figures 39-40; plate IV, figures 5, 6; Figure 3J) from the Lower Silurian of Gotland, Sweden and of Tremanotus tuboides Perner (1903, plate 82, figures 11-15, text-figure 88: Horny', 1963, plate XVIII, figures 1-5) from the Middle Silurian Wenlockian Stage of Central Bohemia. Therefore, Archaeotremaria is quite different from tergomyans, but closely resembles certain gastropods.

Furthermore, the most important distinguishing feature of Archaeotremaria is that the surface of the internal mould bears numerous small pustules, especially on the right side of the paratype (NIGP 54461), where there are four narrow bands, from the median dorsal side, extending slightly backward. Previously Yu regarded these narrow bands as muscle scars in the inner surface ( $\mathrm{Yu}$, $1987 \mathrm{a}$, plate 3 , figures $3-4 ; 1987 \mathrm{~b}$, plate 34 , figures $1-5$, Text figure $52 ; 1990$, plate 7 , figures $1-3 ; 1993$, Text-figure 23). After re-examination of the holotype and the paratype of the type species, I consider that four pairs of muscle scars do not exist. The interior of the shell in the Class Tergomya is characterised by bilaterally symmetrical muscle scars on the bilaterally symmetrical shell.

In summary, it has been shown that Archaeotremaria has a patelliform shell with a series of median dorsal tremata and periodic growth rugae. This combination of characters clearly indicate that Archaeotremaria polytremata is a primitive patelliform gastropod rather than Tergomya.

\section{ACKNOWLEDGEMENTS}

I would like to take this opportunity to thank K.J. McNamara and G.W. Kendrick, Western Australian Museum and two anonymous reviewers. Thanks also to Danielle West and Anne Nevin for their technical assistance.

\section{REFERENCES}

Batten, R.L. (1975). The Scissurellidae - are they neotenously derived fissurellids? American Nuseum Novitates 2567: 1-29.

Berg-Madsen, V. and Peel, J.S. (1994). A tergomyan molluse from the Upper Cambrian of Wales. Palaeontology 37: 505-512.

Chaffee, C. and Lindberg, D.R. (1986). Larval biology of Early Cambrian molluscs: the implication of small body size. Bulletin of Marine Science 139 (2): 526-549.

Clarke, A.H. and Menzies, R.J. (1959). Neopilina (Vema) ewingi, a second living species of the Paleozoic Class Monoplacophora. Science 129: 1026-1027.

Dzik, J. (1981). Larval development, musculature, relationship of Sinuitopsis and related Baltic bellerophonts. Nork Geologisck Tidsskrif 61: 111-121.

Dzik, J. (1991). Is fossil evidence consistent with traditional views of the early metazoan phylogeny? In Simonetta, A.M. and Conway Morris, S. (eds). The early evolution of metazoa and the significance of problematic taxa 47-56, Cambridge: Cambridge University Press and University Camerino.

Esakova, N.V. and Zhegallo, E.A. (1996). Biostratigraphy and fauna of the Lower Cambrian of Mongolia. Transactions, The Joint Russian-Mongolian Paleontological Expedition 46: 1-214 (in Russian).

Golikov, A. and Starbogatov, Y.I. (1975). Systematics of prosobranch gastropods. Malacologia 15: 185-232.

Hall, J. (1865). Account of some new or little known species of fossils from rocks of the age of the Niagara Group.

Haszprunar, G. (1992). The first molluscs - small animals. Bollettino di zoologia 59: 1-16.

Horny', R.J. (1963). Lower Paleozoic Bellerophontina (Gastropoda) of Bohemia. Sbornik Geologickych Ved Paleontologie 2: 57-164.

Horny', R.J. (1965). Cyrtolites Conrad, 1838 and its position among the Monoplacophora (Mollusca). Sbormik Narodniho Muzea V Praze 21: 57-70.

Horny', R.J. and Peel, J.S. (1996). Carcassonnella, a new Lower Ordovician bellerophontiform mollusc with dorsally located retractor muscle attachments (Class Tergomya). Vestnik Ceske'ho geologicke'ho ustavu 71: 305-331.

Knight, J.B. (1941). Paleozoic gastropod genotypes. Geological Society of America, Special Paper, 32: selected pages. Lawrence, University of Kansas Press. 
Knight, J.B. (1947). Bellerophont muscle scars. Journal of Paleontology 21: 264-267.

Knight, J.B. (1952). Primitive fossil gastropods and their bearing on gastropod classification. Smithsonian Miscellaneous Collections 117(13): 1-56.

Knight, J.B. and Yochelson, E.L. (1960). Monoplacophora. In Moore, R.C. (ed), Treatise on invertebrate paleontology. I, Mollusca 1: I77-I84, Lawrence, University of Kansas Press.

Knight, J.B., Batten, R. and Yochelson, E.L. (1960). Description of Paleozoic gastropods. In Moore, R.C. (ed), Treatise on invertebrate paleontology. I, Mollusca 1: selected pages, Lawrence, University of Kansas Press.

Lemche, H. (1957). A new living deep-sea mollusc of the Cambro-Devonian Class Monoplacophora. Nature 179: 413-416.

Lindberg, D.R. (1986). Radular evolution in the Patellogastropoda. American Malacological Bulletin 4: 125.

Lindberg, D.R. (1988). The Patellogastropoda. Malacologic Review, Supplement 4: 35-63. Ann Arbor.

Lindström, G. (1884). On the Silurian Gastropoda and Pteropoda of Gotland. Kungliga Svenska Vetenskapsakademiens Handlinger 19: 1-250.

Linsley, R.M. (1978). Shell form and the evolution of gastropods. American Scientist 66: 432-441.

McLean, J.H. (1984). A case for derivation of the Fissurellidae from the Bellerophontacea. Malacologia 21: 3-20.

Meek, F.B. (1866). Notes on the affinities of the Bellerophontidae. Proceedings of the Chicago Academy of Sciences 1: 9-11.

Missarzhevsky, V.V. (1981). Rennekembrijskie khiolity i gastropodi Mongolli (Early Cambrian hyolithids and gastropods from Mongolia). Paleontologicheskij Zhurnal 1981 1: 21-28 (in Russian).

Moore, R.C. (1941). Upper Pennsylvanian gastropods from Kansas. Bulletin of the Geological Survey of Kansas 38: 121-163.

Peel, J.S. (1972). Observations on some Lower Paleozoic tremanotiform Bellerophontacea (Gastropoda) from North America. Paleontology 15: 412-422.

Peel, J.S. (1991a). The Classes Tergomya and Helcionelloida, and early molluscan evolution. Gronlands Geologiske Undersagelse, Bulletin 161: 1165.

Peel, J.S. (1991b). Salpingostomatiform and related bellerophontacean gastropods from Greenland and the Baltic region, Gronlands Geologiske Undersogelse, Bulletin 161: 67-116.

Perner, J. (1903). Gasteropodes. In: Barrande, J., Systeme Silurien du centre de la Boheme 4, 1: 1-164, Prague.

Reed, P.R.C. (1920-1921). British Ordovician and Silurian Bellerophontacea. Palaeontographical Society, Monographs, London 1-92.

Runnegar, B. and Jell, P.A. (1976). Australian Middle Cambrian molluscs and their bearing on early molluscan evolution. Alcheringa 1: 109-138.

Runnegar, B. and Pojeta, J. Jr. (1985). Origin and diversification of the mollusca. In Trueman, E.R. and Clarke, M.D. (eds). The Mollusca 10, Evolution 1-57. Orlando: Academic Press.
Salvini-Plawen, L. von (1990). Origin, phylogeny and classification of the Phylum Mollusca. Iberus 9: 1-33.

Ulrich, E.O. and Scofield, W.H. (1897). The Lower Silurian gastropoda of Minnesota, in Geology of Minnesota. Final Rept, 3, pt. 2: 813-1081. Minneapolis.

Voronin, Yu. I., Voronova, L.G., Grigor'eva, N.V., Drozdova, N.A., Zhegallo, E.A., Zhuravlev, A. Yu., Ragozina, A.L., Rozanov, A. Yu., Sayutina, T.A., Sysoev, V.A. and Fonin, V.D. (1982). The Precambrian-Cambrian boundary in the geosynclinal areas (the reference section of Salany-Gol, MPR). Trudy Sovmestnoj Sovetsko-Mongol'skoj Paleontologicheskoj Ehkspeditsii 18: 150 pp. Nauka, Moscow (in Russian).

Yin, J.C., Ding, L.F., He, T.G., Li, S.L. and Shen, L.N. (1980). The palaeontology and sedimentary environment of the Sinian System in Emei, Ganluo area, Sichuan. Selected pages. The Sichuan People's Publishing House (in Chinese).

Yochelson, E.L. (1967). Que vadis, Bellerophon? In: Teichert, C. and Yochelson, E.L. eds. Essays in Paleontology and Stratigraphy: 141-161. University of Kansas Press, Lawrence, Kansas.

Yochelson, E.L. (1984). Historic and current considerations for revision of Paleozoic Gastropod Classification. Journal of Paleontology 58: 259-269.

Yochelson, E.L. (1994). Macroscenella (Mollusca) from the Middle Ordovician of Wisconsin a reinterpretation and reassignment. Journal of Paleontology 68: 12521256.

Yu, Wen. (1979). Earliest Cambrian monoplacophorans and gastropods from western Hubei with their biostratigraphical significance. Acta Palaeontologica Sinica 18: 233-270.

Yu, Wen. (1983). A study of the Earliest Cambrian molluscan faunas of Yangtze Region in China. Kexue Tongbao (Chinese Science Bulletin) 28: 1572.

Yu, Wen. (1987a). New molluscan materials of the Tethys. In K.G. McKenzie (ed.). Proceedings of the International Symposium on Shallow Tetheys 2: 51-59. A.A. Balkema, Rotterdam, Netherland.

Yu, Wen. (1987b). The Yangtze micromolluscan fauna in the Yangtze Region of China with notes on PrecambrianCambrian boundary, Stratigraphy and Palaeontology of Systemic Boundaries in China. Precambrian-Cambrian Boundary (1): 19-344. Nanjing University Publishing House, Nanjing, China.

Yu, Wen. (1990). The first radiation of shelled molluscs. Palaeontologia Cathayana 5: 139-170.

$\mathrm{Yu}$, Wen. (1993). On evolutionary trend of shelled molluscs. In: Mu Xinan (ed.). Modern theories and hypothese in the study of palaeontology, 225-254. Science Press, Beijing (in Chinese).

Yu Wen. (1996). Lower Cambrian stenothecoid molluscs from China. Records of the Western Australian Museum 18: 209-217.

Yu, Wen and Yochelson, E.L. (1999). Some Late Cambrian molluscs from Liaoning Province, China. Records of the Western Australian Museum 19: 379-389.

Manuscript received 24 August 2001; accepted 30 July 2002 


\section{Guide to Authors}

\section{Subject Matter:}

Reviews, observations and results of research into all branches of natural science and human studies will be considered for publication. However. emphasis is placed on studies pertaining to Western Australia. Longer papers will be considered for publication as a Supplement to the Records of the Western Australian Muscum. Short communications should not normally exceed three typed pages and this category of paper is intended to accommodate observations, results or new records of significance, that otherwise might not get into the literature, or for which there is a particular urgency for publication. All material must be original and not have been published elsewhere.

\section{Presentation:}

Authors are advised to follow the layout and style in the most recent issue of the Records of the Western Australian Museum including headings, tables, illustrations and references.

The title should be concise, informative and contain key words necessary for retrieval by modern searching techniques. An abridged title (not exceeding 50 letter spaces) should be included for use as a running head.

An abstract must be given in full length papers but not short communications, summarizing the scope of the work and principal findings. It should normally not exceed $2 \%$ of the paper and should be suitable for reprinting in reference periodicals.

The International System of units should be used.

Numbers should be spelled out from one to nine in descriptive text; figures used for 10 or more. For associated groups, figures should be used consistently, e.g. 5 to 10 , not five to 10 .

Spelling should follow the Concise Oxford Dictionary.

Systematic papers must conform with the International Codes of Botanical and Zoological Nomenclature and, as far as possible, with their recommendations.

Synonymies should be given in the short form (taxon, author, date, page) and the full reference cited at the end of the paper. All citations, including those associated with scientific names, must be included in the references.

\section{Manuscripts:}

The original and two copies of manuscripts and figures should be submitted to the Editors, c/Publications Department, Western Australian Museum, Francis Street, Perth, Western Australia 6000 . They must be in double-spaced typescript on A4 sheets. All margins should be at least $30 \mathrm{~mm}$ wide. Tables plus heading and legends to illustrations should be typed on separate pages. The desired position for insertion of tables and illustrations in the text should be indicated in pencil. Tables should be numbered consecutively, have headings which make them understandable without reference to the text, and be referred to in the text

High quality illustrations are required to size $(16.8 \mathrm{~cm} \times 25.2 \mathrm{~cm})$ or no larger than $32 \mathrm{~cm} \times 40$ $\mathrm{cm}$ with sans serif lettering suitable for reduction to size. Photographs must be good quality black and white prints, not exceeding $16.8 \mathrm{~cm} \times 25.2 \mathrm{~cm}$. Scale must be indicated on illustrations. All maps, line drawings, photographs and graphs, should be numbered in sequence and referred to as Figure/s in the text and captions. Each must have a brief, fully explanatory caption. On acceptance a computer disk containing all corrections should be sent with amended manuscript. The disk should be marked with program (e.g. Word, WordPerfect, etc).

In papers dealing with historical subjects references may be cited as footnotes. In all other papers references must be cited in the text by author and date and all must be listed alphabetically at the end of the paper. The names of journals are to be given in full.

\section{Processing:}

Papers and short communications are reviewed by at least two referees and acceptance or rejection is then decided by the editors.

The senior author is sent one set of page proofs which must be returned promptly

The senior author will receive fifty free offprints of the paper. Additional offprints can be ordered at page proof stage. 


\section{Records of the Western Australian Museum Volume 21 Part 32002}

\section{CONTENTS}

\section{M.J. Fletcher and M.L. Moir}

Cryptobarsac rubriops, a new genus and species of selizine Flatidae (Hemiptera:

Fulgoromorpha) from grasstrees (Xanthorrhoea preissii) in south

Western Australia

J.M. Waldock

Redescription of Lycidas chrysomelas (Simon) (Araneae: Salticidae)

M.C. Ebach and K.J. McNamara

A systematic revision of the family Harpetidae (Trilobita)

F.E. Wells

Seasonality of beachwrack at Oakajee in the mid-west region of Western Australia

K.D. Smith, B. Knott and E.J. Jasinska

Biology of the Black-stripe minnow Galaxiella nigrostriata, (Galaxiidae) in an acidic, black-water lake in Melaleuca Park near Perth, Western Australia

K.D. Smith, L.J. Pen and B. Knott

Genetic and morphological study of the Black-stripe minnow, Galaxiella nigrostriata (Salmoniformes: Galaxiidae), including a disjunct population near Perth, Western Australia

B. Knott, E.J. Jasinska and K.D. Smith

Limnology and aquatic fauna of EPP 173, Melaleuca Park, refuge for an outlier population of the Black-stripe minnow Galaxiella nigrostriata (Galaxiidae),

in southwestern Australia

Yu Wen

Very old patelliform gastropods from the Early Cambrian of China:

Reconsideration of the systematic position of Archaeotremaria 